\title{
Information and Communication Technology Management Support and Service Delivery at the Department of Immigration, Kenya
}

\author{
Gladys Kangogo Komen (Corresponding author) \\ Jomo Kenyatta University of Agriculture and Technology, Kenya \\ E-mail: gladyskomen@gmail.com \\ Thomas Anyanje Senaji \\ Jomo Kenyatta University of Agriculture and Technology, Kenya
}

Received: September 8, 2020 Accepted: October 15, 2020 Published: October 21, 2020

doi:10.5296/ijssr.v9i1.17657 URL: http://dx.doi.org/10.5296/ijssr.v9i1.17657

\begin{abstract}
Service delivery is a major function of the State Department of Immigration and there are some ICT factors which may influence the provision of quality services to citizens. We examined the relationship between the ICT Management support and service delivery at Department of Immigration passport control office in Nairobi Kenya using a descriptive survey design with sample size of 192 respondents with questionnaires for data collection. The data was analyzed using SPSS 22 software where descriptive statistics were calculated which comprised means and standard deviation while Chi square statistics were used to assess the association between variables. We found a significant association between ICT management support and service delivery $x^{2}=0.740(\mathrm{p}=0.786>0.05)$. Based on this finding it is recommended that the Government ensures sufficient ICT funding, innovate ICT policies and strategies to cater for new ICT trends that are necessary for improved service delivery. Further, there is need to regularly review ICT standards and regulations to reflect the dynamic nature of the technology used in service delivery.
\end{abstract}

Keywords: service delivery, ICT, management support, immigration department Kenya 


\section{Introduction}

Public organizations have realized the potential of the information and communications technologies (ICT) to improve efficiency in their operations. This paper focuses on assessing the relationship between management support for ICT implementation and service delivery at the Department of Immigration Kenya. Immigration services Department is a Government office which is mandated to deliver services to the public. The services include issuance of passports, permits, visas, foreign certificates, citizenship, permanent residency, and border control, in view of all these services the Department have implemented some mechanisms to improve service delivery. The use of ICT is very important in the Department for effective and efficient service delivery. The adoption of ICT may have improved efficiency at the passport offices in Nairobi but the management support for the ICT may also influence the quality of service delivery to the citizens.

The ICT Management support includes ICT policy, ICT infrastructure and ICT Budget, each organization formulates ICT policy use and strategy, this policy will be implemented for effectiveness in use ICTs and the strategy of using them to improve service delivery. An ICT budget if allocated and utilized well can led to improvement of ICT infrastructure. The Management support for ICT infrastructure may include the maintenance of Hardware, software and Internet infrastructure. In an organization when system fail then the service provision fails and finally the quality service delivery will not be achieved.

Top management support is considered to be a top critical success factor in project management, its involvement can significantly improve a project success (Ahmed 2016). Organizations around the world are looking for development and keeping up to date with the emerging technologies, they pay more attention to improve its ICT infrastructure to improve productivity.

By the beginning of the new millennium there has been global interest in undertaking major ICT initiatives such as E- Government (Mofleh et al., 2017). According to Gandomi and Haider (2015), the adoption of ICT in the public sector started in 1970s and evolved over decades until the use of E-Government initiatives. Such initiatives were deemed effective tools to be deployed to accomplish public sector reforms. These initiatives were recommended and mostly funded by international donors such as UN and World Bank for social and economic growth in emerging and developing countries. Despite the global investment on the ICT initiatives the success has not being achieved due to the E-initiative such as E-government failure to deliver the promised output (Cibbora et al., 2005). ICT has become the foundation of success in every sector economy globally. ICT has played a critical role in service delivery in terms of transparency, efficiency and accuracy in transacting business and providing services. According to Mwai (2013), ICT has brought dynamic changes on ways of delivering services to customers in an organization, this has led to restructuring of business operations to align to the new technologies for better service delivery.

Many countries have started fostering ICT services accessibility policy frameworks on access to Government services through Government websites (ITU, 2017). The ICT services need to be regulated to avoid being misused, the regulations followed are in line with ITU 
recommendations to ensure worldwide connectivity. An example of inadequacy of information is the observation by Maime (2014) that South Africa suffers information poverty which is lack of access and utilization of ICT as well as services that they facilitate. In regards to Lesotho, the Government have been trying to move forward to enhance in ICT and E-government initiatives. By the year 2020, the Government of Lesotho aims at undertaking reforms at the public sector that included computerization of systems to improve manual and slow in information handling as well has eliminating loss of vital information and improve work flow (International Record Management trust, 2006).

According to UNDP report (2001), Kenya's public sector was merged with lots of inefficiencies and hence need to transform the public sector service delivery. The UNDP report (2018) emphasized on the expansion of data availability and new opportunities for innovation. The technologies strengthen analysis and innovation. To achieve this Rapid Result initiative was introduced and a one stop shop for all Government services was to be introduced which later became the E-citizen. The mechanism to ensure service delivery included ICT applications on the processes and use of technology to input, process, transmit and presentation of processed data is applied in passport application, receiving, scanning, security clearance, recommendation, approval, printing and passport delivery.

The Government of Kenya in vision 2030 have emphasized on automation of all government services (GOK 2010). The quantity of E-transactions has increased and hence the administration was pushed to build an online platform which directly connected to the government functions with minimal interaction to the government employees. E-government is the utilization of ICT and other telecommunication to enable citizens reach Government services with the help of Internet (Gajendra, Xi, \& Wang, 2012). This led to introduction of E-government which enables citizens to handle several government services on one platform which is E-citizen. The E-citizen was used at the Immigration Department passport section to apply for passport and make payment. The applications on this platform is connected to E-passport management system for ease in populating data during processing. The Department of Immigration Kenya is a Government office which is supported by the Government to ensure quality service delivery. ICT for development (ICT4D), is interpreted as the use of ICT to deliver greater good (Weigel \& Waldburger, 2003).

The need for deployment and support of ICT implementation in Government Departments notwithstanding, the extent to which the Government as the service provider ensures that they support the ICT development through funding, policy and strategy formulation, ICT infrastructure development and how this relates with service delivery as perceived by the citizens who seek these services on daily basis is scarcely documented in empirical literature.

\subsection{General Objectives}

To assess the relationship between Information and Communication Technology Management Support and Service Delivery at the Department of Immigration, Kenya.

\subsubsection{Specific Objectives}

1) To determine the relationship between management support for ICT policy and service delivery at the Department of Immigration, Kenya.

2) To determine the relationship between Management support for ICT infrastructure and 
maintenance and service delivery at Department of Immigration, Kenya.

3) To determine the relationship between ICT budget and service delivery at the Department of Immigration, Kenya.

\section{Literature Review}

Marshall and Rossman (2006) explain that a literature review is a "thoughtful and logical discussion of related literature which builds a logical framework for the research and locates it within a tradition of enquiry and context of related studies". These literature review covered related studies and theories on service delivery and ICT management support and a conceptual framework to guide the study was also presented. Empirical review was presented to enable identify past literature-e related to the study. The theories and models used in the study was system approach theory and Technology Acceptance Model (TAM).

\subsection{Theoretical Literature}

\subsubsection{Systems Approach Theory}

According to (Teeboom, 2018), System Approach Theory is the view of an organization as an open social system that must interact with their environment in order to survive and public relation is essential to help an organization adjust and adopt to changes in an organization. The identification of service delivery with customer satisfaction has been established over time, customer satisfaction can build good image of the organization. Service delivery involves a comparison of expectations with performance. The performance improvement can be measured through the measure of customer satisfaction and an improvement of the service delivery can attract more customers and retain a good public image of an organization (Albattat, Yajid, \& Khatibi 2019).

The systems approach thus views the organization, in this case service provider, as a unified, purposeful system composed of interrelated parts. This theory gives a clear direction on the basics of measuring service through service reliability by giving the main consideration to arriving at more concise measurement variables. Its linked to service delivery and it is very useful in this study for its assistance in determining how service delivery at Immigration Department can be measured using the perceived (according to the respondents' opinions). The study will therefore be able to relate the independent variable to the dependent variable effectively.

\subsubsection{Technology Acceptance Model}

The TAM (Davis, 1986) models how users' uptake and use a new technology. The model suggests that when a new technology is introduced into the market a number of factors influences users' decision about how and when they will use it. TAM is based on two factors: perceived usefulness and perceived ease of use (Rondan, Arenas, \& Ramirez, 2015), Perceived usefulness is the degree to which a person believes that by using a new technology it would improve their productivity, whereas Perceived ease-of-use describes the degree into which an individual believes that using a particular technology would be free from effort, both this factor affects service delivery.

This model is linked to the management support where the management should be able to support the adoption and use of ICTs in their operations through in ICT policy formulation, ICT infrastructure deployment and system maintenance, The TAM also models how the 
management of the Department of Immigration allocated ICT budget for all ICT operations to run smoothly. Further, the model suggests that management need to train employees on ICT skills for them to be able to adopt and accept new technology. Of importance is that the users should be able to perceive the technology as being useful in improving productivity and as being easy to use. This model is important in that these two factors then determine the attitude of the user towards using the technology.

The model also goes on to say that the Perceived Usefulness will also influence the behavioral intention to use. The attitude determines the behavior which in turn influences the actual acceptance. This proposition is plausible because the attitude of the people using it will help to analyze if it is helpful in terms of ease of use and productivity and its used to enhance quality service delivery.

We then conceptualized the association between ICT management support and service delivery by considering three aspects of ICT management support, namely ICT Policy, infrastructure and system maintenance; and budget. We also operationalized service delivery using five indicators, these were number of applications received and biometrics taken, number of passports processed, average queuing time before being served, average waiting time to collect ready passport, and the number of passports printed and delivered to applicants. The conceptual framework is presented as Figure 1.

\subsection{Conceptual Framework}

\begin{tabular}{|l|l|l|}
\hline ICT Management support & $\begin{array}{l}\text { Service Delivery } \\
\text { - ICT Policy }\end{array}$ \\
- ICT infrastructure and system & $\begin{array}{l}\text { Number of applications received and } \\
\text { biometrics taken }\end{array}$ \\
- maintenance & $\begin{array}{l}\text { Number of passports processed } \\
\text { - The average queuing time before being served } \\
\text { - The average waiting time to collect ready } \\
\text { passport } \\
\text { - The number of passports printed and delivered } \\
\text { to applicants }\end{array}$ \\
\hline
\end{tabular}

Figure 1. Conceptual framework

\subsubsection{ICT Management Support}

This is the willingness of the top management to support on policy formulation, ICT infrastructure development and Budget allocation. These variables were measured by existence of supportive ICT policy, maintenance of ICT infrastructure and adequacy of budget for ICT system. In this case the management support is important because without it there will be failure within the organization. The success or failure of a project in an organization depends on the intensity of support from the top management and plays a significant role in the outcome (Ahmed, 2016). To provide strong support during implementation of projects the top management should take leadership role (Talib, Rahman, 
\& Qureshi, 2011). ICT policy is important in an organization to assist in guiding the department on ICT use and requirements. The ICT infrastructure include system maintenance where the hardware is maintained, software updated and internet is reliable.

\subsubsection{Service Delivery}

Service delivery was relevant to this study in that its dependent on the ICT management support, Service delivery was measured by how well performances matches customers' expectations (Coye, 2004). The Department of Immigration measured service delivery by the number of applications received and biometrics taken, the number of passports processed, the average queuing time before being served, the average waiting time to collect ready passport and the number of passports printed and delivered to applicants (Immigration department statistical reports, 2018). The relationship between the independent variables and service delivery was investigated.

\subsection{Empirical Literature Review}

Empirical studies on management support for ICT and service delivery are reviewed.

\subsubsection{Management Support of ICT and Service Delivery}

ICT Management support includes ICT policy, ICT infrastructure and ICT budget allocation. An organization which lacks enough management support tend to lower the quality of service delivery. Top management support plays a significant role in project outcome (Ahmed, Mohamed, \& Ahamed, 2016) and its success and failure depend on top management intensity to its support.

Ahmed (2016) study on top management support and project performance of public sector project, investigated the relationship between multiple dimensions of top management support and project performance, it was that top management support had a significant positive influence on project performance in public sector of Pakistan. The study recommended policy formulation to gain support from top management to improve project performance.

According to Normand et al. (2002) assessed the development of community clinics in Bangladesh and established that service delivery was largely determined by faculties' services and management support. The findings indicated that deficiencies in equipment required which is a reflection of budget provision by management, affected service quality negatively. Around the world, Governments are implementing initiatives to reform public sector because citizen's expectations for efficient and effective services and for a voice in their design and delivery has increased. Consequently, empirical literature suggests that management support for ICT in the form of policy, infrastructure and system maintenance, and budget are necessary to ensure satisfactory service delivery to the public within the wider framework of e-government such as should be the case for Department of immigration services.

\subsubsection{Service Delivery}

Public service delivery is a set of institutional arrangements adopted by the government to 
provide public good or services to its citizens (UNDP, 2018). There are two approaches to achieve service delivery namely, Government development approach and public participation (Quick et al., 2016). In the Government approach, resources, capacity and strategy development can help in ensuring effective providing service delivery whereas in the public participation approach, mechanism ought to be put in place to ensure the public participate fully in customer's sensitization as they are required to improve their satisfaction on the services offered by the government (Grageda, 2019).

In Kenya, Muthui (2016) examined factors influencing service delivery at the county government including, public participation, resource mobilization (including budgeted finances) and accountability by local leaders. The methodology was descriptive research design and the target population was residents of Kitui county and questionnaires was administered which was analyzed by use of SPSS and regression analysis. It was found that there was inadequate public participation and lack of accountability and transparency by leaders. It was recommended that there be an increase in allocation of financial resources, and publish public meeting for all to see and attend. These findings were relevant to this study with regard to the need by management need to support ICT infrastructure in terms of policy formulation and financial support.

\section{Methods}

\subsection{Research Design}

A descriptive research design was used since the aim was to describe the state of management support for ICT at the Immigration Department and how this support related with service delivery as perceived by the citizens. The design allowed in-depth study of the subject matter (Kothari, 2002). Descriptive research was used to describe the relationship between ICT management support and service delivery at the Department of Immigration Passport control office Nairobi.

\subsection{Target Population}

The study targeted 170 employees of all ranks working at the passport control office. They were surveyed using self- administered questionnaires to obtain their views on ICT management support and service delivery.

\subsection{Data Collection Instruments}

Data instruments are tools used to collect data from the respondents. The questionnaire contained a series of open and closed ended questions which were valid and reliable. The questions covered all independent and dependent variable. According to Mugenda and Mugenda (2003), questionnaires are commonly used to obtain information from the study population. Structured questionnaires with items anchored on a five-point Likert type scale was used with $1=$ strongly disagree, $2=$ Disagree, $3=$ moderately agree, $4=$ Agree and $5=$ strongly agree. 


\section{Macrothink}

\subsection{Data Analysis}

According to Kothari (2004), data analysis means analyzing, categorizing, ordering, manipulation and summarizing data to obtain answers to research questions and its purpose is to obtain meaningful information. The data was cleaned and eliminating errors before being analyzed then computed using SPSS 22. Data were analyzed using descriptive and inferential techniques respectively to generate descriptive statistics that's mean and standard deviation and inferential statistics that is chi square.

\section{Results}

The results of the study comprising frequency distribution responses, descriptive results and inferential results are presented in this part.

\section{Frequency distributions}

Data was collected on gender, job function and highest level of education of the respondents; data on the experience of the respondents in years in the organization was also collected and frequencies generated.

\section{Gender and position held by respondents}

The respondents of the study were $37.5 \%$ male and $62.5 \%$ female. This response indicates that there were more women than men.

The respondents held different positions at the department of Immigration, $62.5 \%$ of the respondents were immigration officers, $20.3 \%$ were clerical officers, and $9.4 \%$ were ICT officers' while only $7.8 \%$ of the respondents were intern category. This implied that majority of the respondents were immigration officers and their responses were valid due to their job description.

\section{Highest level of education}

The respondents had different levels of education, the level of education was important in enabling the respondents to conceptualize issues related management support for ICT and to service delivery in the organization. The distribution of responses by level of education is presented in Figure 2.

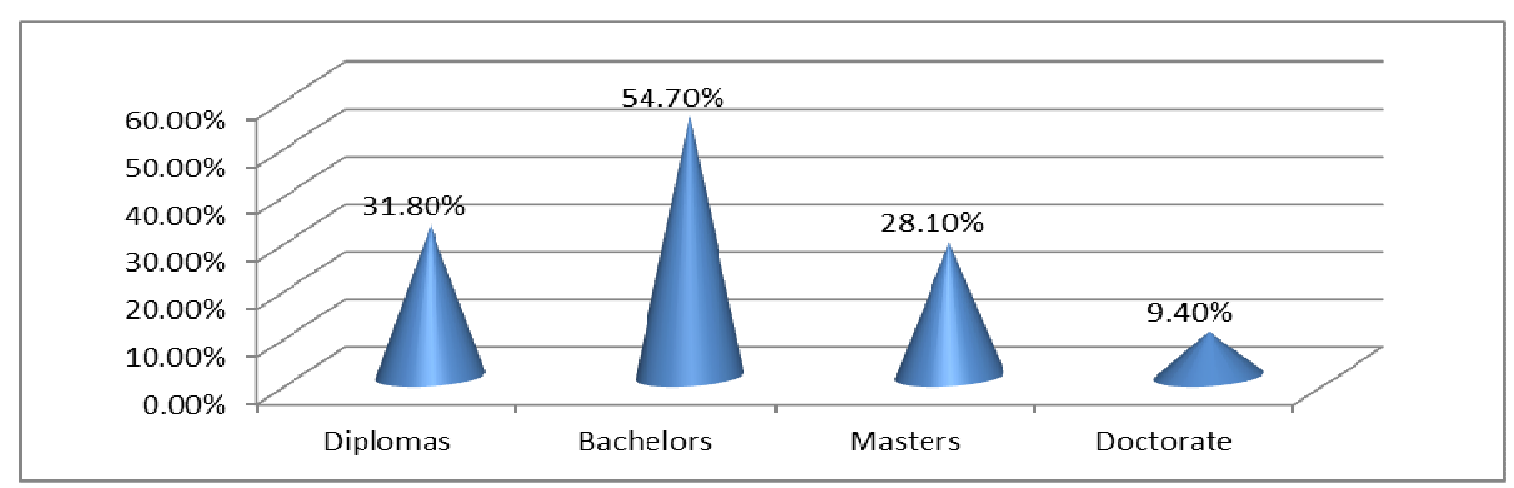

Figure 2. Level of education 
It was established from the study that $54.7 \%$ of the respondents had bachelors, $31.8 \%$ had diplomas, $28.1 \%$ had masters, and $9.4 \%$ of the respondents had doctorate degrees. As seen from this result (Figure 2) majority of respondents working in Department of immigration, Nairobi, had bachelor degree qualifications. The implication is that the respondents were suitable to respond to the survey given the information that was sought on management support and on issues of service delivery.

\section{Work section and experience}

With regard to the work section of the respondents, the majority of the respondents $48.4 \%$ worked at the passport printing section, 17.2\% Passport acceptance and queuing respectively, 8.1\% worked at Passport Processing, 6.3\% worked at Passport delivery and ICT section respectively while $4.7 \%$ worked at Customer care.

It was also found that the majority (54.7\%) had worked for 1-2 years, $28.1 \%$ had for 3-5 years while those who had worked over five years were $12.5 \%$. A small group had worked for less than 1 year at $4.7 \%$. According to (Holman et al., 2008) working duration is associated with greater output, in a given industry and knowledge of the organization. Consequently, the respondents had worked at the station long enough to be able to provide accurate responses.

\section{ICT management support}

The success or failure of a project in an organization depends on the intensity of support from the top management and plays a significant role in the outcome (Ahmed, Mohamed, \& Ahamed, 2016). In this case the management support is important because without it there will be failure within the organization. The management support on ICT infrastructure, ICT policies is very important in an organization because it affected service delivery.

On the statement whether the employees were aware of existence of ICT policies in department of Immigration. From the study findings, Majority $67.2 \%$ of the respondents said they were aware of existence of ICT policies in department of immigration while $32.8 \%$ were not aware.

\section{Existence of ICT policies in department of Immigration}

On the extent management support affects service delivery at the organization, the results found out that $80 \%$ of the respondents indicated that management support affects the Service delivery while $20 \%$ of them indicated that Management support does not affect service delivery

\section{Whether management support affected Service delivery}

The extent to which Management support affected Service delivery, according to the results, $40 \%$ of the respondents indicated that management support affected Service delivery to a moderate extent, $28 \%$ to a very great extent, $26 \%$ to a great extent, $4 \%$ to a little extent while only $2 \%$ of the respondents indicated that management support does not affect service delivery. 


\section{Management support}

The respondent's level of agreement to the statements on management support (on a scale of 1 (strongly disagree) to 5 (strongly agree) were investigated and the results were presented on Table 1.

Table 1. Management support

\begin{tabular}{lll}
\hline Statement & Mean & SD. \\
\hline The ICT policy is supportive of service delivery & 4.4 & 0.3 \\
The top management supportive of ICT infrastructure & 4.0 & 0.2 \\
There is sufficient Budget to implement ICT & 4.3 & 0.3 \\
The ICT strategy is responsive to service delivery & 4.6 & 0.1 \\
\hline
\end{tabular}

It was observed that the ICT strategy was responsive to service delivery as shown by a mean of 4.6; that ICT policy is supportive of Service delivery at Department of immigration Nairobi as shown by a mean of 4.4; that there was sufficient budget to implement ICT linked with Service delivery needs at Department of immigration Nairobi as shown by a mean of 4.3; that the top management is supportive of ICT infrastructure as shown by a mean of 4.0. The findings are indicated in Table 1.

\section{Barriers to use ICT for service delivery}

The challenges faced by using ICT for service delivery at the passport control office were investigated and the responses presented

Table 2. barriers to use ICT for Service delivery

\begin{tabular}{lll}
\hline Challenge & Yes & No \\
\hline Lack of ICT facilities & 64.1 & 35.9 \\
Shortage of ICT Skills & 60.9 & 39.1 \\
Breakdown of machines & 84.4 & 15.6 \\
Changes in technology & 59.8 & 40.2 \\
Lack of cooperation among employees in adopting ICT & 70.25 & 29.75 \\
\hline
\end{tabular}

From the study results $64.1 \%, 60.9 \%, 84.4 \%, 59.8 \%$ and $70.25 \%$ agreed that Lack of ICT facilities, Shortage of ICT Skills, breakdown of machines, changes in technology respectively and Lack of cooperation among employees in adopting ICT affected service delivery. The findings are indicated in Table 2.

\section{ICT infrastructure}

The respondent's opinion on statements about Technology were distributed and presented in 
Table 3.

Table 3. Respondents rating of various statements about technology performance

\begin{tabular}{lll}
\hline Statements & Mean & SD. \\
\hline There is frequent hardware failure & 3.9 & 0.3 \\
The software used are obsolete and interfere with operations & 2.5 & 0.2 \\
There is frequent internet downtime and affect operations & 2.2 & 0.3 \\
There is frequent system maintenance & 3.3 & 0.2 \\
\hline
\end{tabular}

From the results, respondents agreed that there is frequent hardware failure as shown by a mean of 3.9; that there is frequent system maintenance as shown by a mean of 3.3; The software used are obsolete and interfere with operations as shown by a mean of 2.5. They disagreed that there is frequent internet downtime and affect operations as shown by a mean of 2.2. The adoption of Technology on Service delivery activities can be considered as strategic in so far as these activities can impact structures and can in particular create value from intangibles in business activities. (Choong, 2008). The findings are indicated in Table 3.

\section{Status of service delivery}

The status of service delivery at the passport control office was represented by the services offered were application submission and acceptance, Biometrics, customers care and passports collection. The customers gave their views on the services as shown by Table 4

Table 4. Status of service delivery

\begin{tabular}{llllll}
\hline & N & Range & Minimum & Maximum & Mean \\
& Statistic & Statistic & Statistic & Statistic & Statistic \\
\hline Application submission & 90 & 4 & 1 & 5 & 2.43 \\
Biometrics & 90 & 4 & 1 & 5 & 2.63 \\
Customer care & 90 & 5 & 0 & 5 & 1.89 \\
Collection & 90 & 5 & 0 & 5 & 1.31 \\
Valid N (list wise) & 90 & & & & \\
\hline
\end{tabular}

The service that was rated least favorably by customers was collection $(\mathrm{M}=1.31)$ followed by customer care $(M=1.89)$. The best rated service was biometrics $(M=2.63)$ followed by application submission process $(\mathrm{M}=2.43)$. It is noted that the mean scores are within disagreement $(\mathrm{M}=2.00)$ and strong disagreement $(\mathrm{M}=1.00)$ with statements that were aimed at assessing the satisfaction of customers with the passport services. This implies that the service delivery was poor $(\mathrm{M}<3.0)$. 


\section{Macrothink}

International Journal of Social Science Research

ISSN 2327-5510

2021, Vol. 9, No. 1

Table 5. Descriptive statistics of service delivery and ICT supply and demand factors

\begin{tabular}{llllllll}
\hline & $\mathrm{N}$ & Mean & Std. Deviation & Skewness & \multicolumn{3}{c}{ Kurtosis } \\
\hline Variables & Statistic & Statistic & Statistic & Statistic & Std. Error & Statistic & Std. Error \\
Management support & 64 & 2.70 & 0.43 & -0.276 & 0.299 & 0.067 & 0.59 \\
Service delivery & 64 & 2.51 & 1.29 & 0.417 & 0.254 & -0.971 & 0.503 \\
\hline
\end{tabular}

From the mean statistics, there was unsatisfactory ICT management support and also unsatisfactory $(\mathrm{M}=2.70, \mathrm{SD}=0.43)$, however, it showed that service delivery $(\mathrm{M}=2.5, \mathrm{SD}$ $=1.29$ ).

Responses on service delivery and ICT management support were binary coded as follows:

$$
\begin{aligned}
& \text { Service delivery } y^{*} \text { (binary): } y^{*}=\left\{\begin{array}{c}
1, \text { (good) for } \mathrm{y}>=3.5 \\
0,(\text { poor) for } \mathrm{y}<=3.5
\end{array}\right. \\
& \text { ICT management support (binary) } x^{*}=\left\{\begin{array}{c}
1, \text { (good) for } \mathrm{x}>=3.5 \\
0,(\text { poor) for } \mathrm{x}<=3.5
\end{array}\right.
\end{aligned}
$$

As seen from the foregoing, service delivery binary was also coded as good when the mean was greater than 3.5 and poor when less than 3.5. Similarly, the ICT management support were coded as 1 when the mean response was greater than 3.5 and 0 when it was less than 3.5 .

\section{Discussions and Conclusion}

Based on the finding of the study, the following conclusion and recommendations are made:

\subsection{Conclusion}

Pertaining ICT management support, the study found out that management support on ICT infrastructure affected service delivery as shown by a significant association between them. The study concluded that when the management support the ICT infrastructure and existing policies its improved service delivery. Finally, the findings concluded that there is a significant association between service delivery and ICT management support and further shows a significant association as shown by Chi square as $\mathrm{p}>0.05$. Management support of ICT infrastructure at $x^{2}=0.740(\mathrm{p}=0.786>0.05)$.

\subsection{Management Support}

According to Dietrich et al. (2016) on improved Municipal service delivery through integrated maintenance, ascertained that maintenance of public infrastructure will help to achieve service delivery. The management should ensure the software used is not obsolete and fully licensed. The management should include local technical staff to assist when the machines fail unlike now at the department of immigration the passports printing machines technicians are from Pakistan and Germany which is costly in travelling cost and takes time in case of emergency. 


\section{Macrothink}

International Journal of Social Science Research

ISSN 2327-5510

2021, Vol. 9, No. 1

In Kenya, The Communication Authority of Kenya (CAK) and ICTA mandated to implement ICT policies and strategies. With their support and budget allocation, the ICT will be improved in Kenya (G.O.K., 2016). ICT infrastructure includes system maintenance that Hardware, software and internet, when they are not maintained it tend to fail and affects service delivery. Obsolete software can affect the delivering of services.

\subsection{Service Delivery}

Service delivery clearly needs a significant improvement at the department of immigration, the findings indicated poor service delivery and hence recommend speedy processing of passports and to eliminate long queues and processes paper work should be eliminated and passports delivered via courier services to the owners at the nearest Posta offices within Kenya. The printing machines should be up to date with new trends to avoid obsolete machines and ICT infrastructure. ICT infrastructure ought to be given priority in terms of funding, policies formulation and strategies to be able to meet the new trends.

\section{Acknowledgement}

I wish to convey my sincere gratitude to my family for financial and emotional support when undertaking this project. To Thomas Senaji for dedicated support and guidance in proofreading and positive feedback and finally to all my colleagues and friends for their constructive and encouraging contribution.

\section{References}

Ahmed, R. (2016). Top Management Support and Project Performance: An Empirical Study of Public Sector Projects. SSRN Electronic Journal. https://doi.org/10.2139/ssrn.3044377

Albattat, A., Yajid, M., \& Khatibi, A. (2019). The determination of shopping satisfaction of tourists visiting One Utama shopping mall. Management Science Letters, 9(13), 2291-2304. https://doi.org/10.5267/j.msl.2019.7.025

American Psychological Association. (2010). Publication Manual of the American Psychological Association. Washington DC: Author.

Choong, K. K. (2008). Intellectual capital: definitions, categorization and reporting models. Journal of Intellectual Capital, 9(4), 609-638. Emerald Group. https://doi.org/10.1108/14691930810913186

Ciborra, C., \& Navarra, D. D. (2005). Good governance, development theory, and aid policy: risks and challenges of e-government in Jordan. Information Technology for Development, 11(2), 141-159. https://doi.org/10.1002/itdj.20008

Coye, R. W. (2004). Managing customer expectations in the service encounter. International Journal of Service Industry Management, 15(1), 54-71. Emerald Group Publishing Limited. https://doi.org/10.1108/09564230410523330

Davis, F. (1986). Technology Acceptance Model. Massachusetts: Massachusetts Institute of Technology Publishers. 


\section{Macrothink}

International Journal of Social Science Research

ISSN 2327-5510

2021, Vol. 9, No. 1

Dietrich et al. (2016). Improved municipal service delivery through integrated maintenance. South Africa.

Gandomi, A., \& Haider, M. (2015). International Journal of information management. Canada: Elsevier publisher.

Grageda, K. C. (2019). Partner for review, the whole of Government approach. Federal ministry for economic cooperation and development.

Holman, C., Joyeux, B., \& Kask, C. (2008). Labor productivity trends since 2000, by sector and industry. Monthly Labor Review, 64-82. Retrieved September 5, 2020, from http://www.jstor.org/stable/monthlylaborrev.2008.02.064

Immigration Department Kenya. (2018/2019). Monthly Statistical Reports.

International Record management trust. (2006). Fostering trust and transparency in Governance. London: International record management trust.

ITU. (2017). Access to Telecommunication \& ICT services by people living with disability. Switzerland: Telecommunication Development Bureau Publishers.

Kenya Constitution. (2010). Citizenship, Chapter three and Chapter four Bill of Rights. Nairobi: Government Printers Publishers.

Kothari, C. R. (2004). Research Methodology. Methods and Techniques (2nd ed.). New Delhi: New Age International.

Maime, R. B. (2014). Challenges and opportunities of adopting management information system for passport processing, comparative between Lesotho and South Africa. South Africa: Central University of Technology.

Marshall, C., \& Rossman, R. B. (2006). Designing Qualitative Research (4th ed., p. 262). Thousand Oaks: Sage Publication.

Mofleh, S., Wanous, M., \& Strachan, P. (2017). Developing Countries and ICT Initiatives: Lessons Learnt from nom Jordan's Experience. Wiley online library.

Mugenda, O. M., \& Mugenda, A. G. (2003). Research Methods Quantitative and Qualitative Approaches. Nairobi: Acts Press.

Muthui, A. (2016). Factors influencing service delivery at the county government. Nairobi: KCA University School of business and administration.

Mwai, P. M. (2013). ICT and service delivery in Kenya Power. University of Nairobi. Kenya.

Normand, C., Iftekar, M. H., \& Rahman, S. A. (2000). Assessment of the community clinics: effects on service delivery, quality and utilization of services. Bangladesh.

Quick, K. S., \& Bryson, J. (2016). Handbook in Theories of Governance. Edward Elgar Press.

Rondan, C. F., Arenas, G. J., \& Ramírez, C. P. (2015). A comparison of the different versions 


\section{Macrothink \\ International Journal of Social Science Research \\ ISSN 2327-5510 2021, Vol. 9, No. 1}

of popular technology acceptance models. Bingley: Emerald Group Publishing Limited.

Talib, F., Rahman, Z., Quershi, M. N., \& Siddique, J. (2011). Total quality management and service quality: an exploratory study of management practices and barriers in service industries. International Journal of Services and Operations Management (IJSOM), 10(1), 94-118. https://doi.org/10.1504/IJSOM.2011.041991

Teeboom, L. (2018). Application of Systems Theory in Business Organizations. Small Business - Chron.com. Retrieved from http://smallbusiness.chron.com/application-systems-theory-business-organizations-73405.ht $\mathrm{ml}$

UNDP. (2018). Improving service delivery in Kenya. Nairobi: UNDP publishers.

Weigel, G., \& Waldburger, D. (2003). ICT4D—Connecting People for a Better World Lessons, Innovations and Perspectives of Information and Communication Technologies in Development. Berne and Kuala Lumpur: Swiss Agency for Development and Cooperation (SDC) and Global Knowledge Partnership (GKP).

\section{Copyrights}

Copyright for this article is retained by the author(s), with first publication rights granted to the journal.

This is an open-access article distributed under the terms and conditions of the Creative Commons Attribution license (http://creativecommons.org/licenses/by/4.0/). 